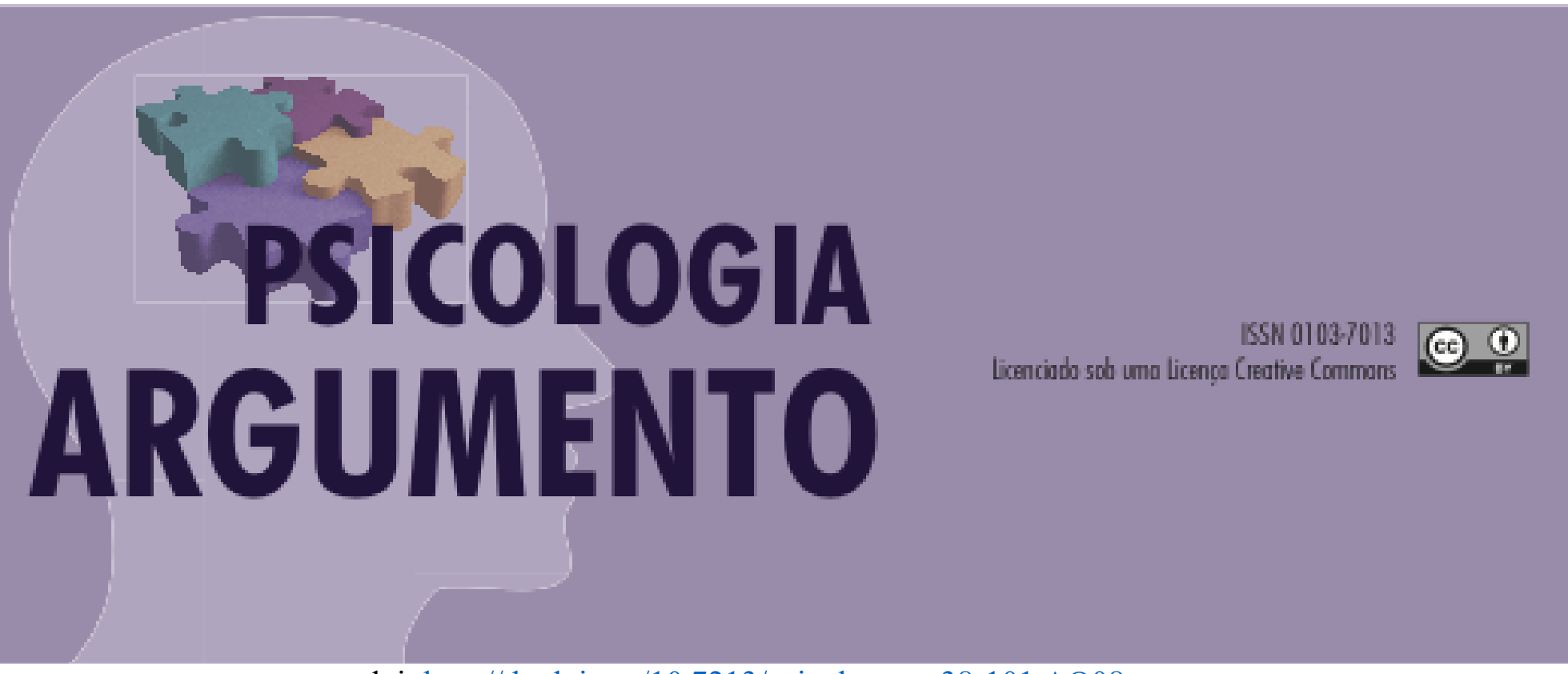

doi: http://dx.doi.org/10.7213/psicolargum.38-101.AO08

\title{
A condição universitária e a vivência parental
}

\author{
University student condition and parental experience
}

Condición universitaria y experiencia parental

\begin{abstract}
Carolina Serrati Moreno
Graduanda em Psicologia - Universidade Federal de São Carlos (UFSCar). E-mail: caarol.moreno@gmail.com. Orcid: https://orcid.org/0000-0002-9222-4102

\section{Giovanna Maria Duarte}

Graduanda em Psicologia - Universidade Federal de São Carlos (UFSCar). E-mail: giovannaduarte1998@hotmail.com. Orcid: https://orcid.org/0000-0003-0282-2617

\section{Sabrina Mazo D'Affonseca}

Professora do Departamento de Psicologia e do Programa de Pós Graduação em Psicologia da Universidade Federal de São Carlos. Pesquisadora do Laboratório de Análise e Prevenção à Violência (Laprev). E-mail: samazo@ufscar.br. Orcid: https://orcid.org/0000-0001-9103-0616
\end{abstract}

\section{Resumo}

A vivência de universitários com filhos é muito complexa pela união de dois processos com demandas específicas e difíceis de serem conciliadas. Todavia, vários jovens passam por essa situação e lidam com isso de diversas formas possíveis de acordo com as suas prioridades. Notase que alguns fatores como gênero e rede de apoio modificam como a experiência acontece, ditando a quantidade de responsabilidades e a autopercepção dessas pessoas como estudantes e como pais. Com base nesses fatores, o objetivo deste estudo foi de compreender as vivências e o envolvimento parental de jovens universitários da graduação que possuem filhos. A pesquisa foi realizada de forma qualitativa e transversal, com quatro graduandos (dois pais e duas mães) de uma universidade do interior do estado de São Paulo, com idade entre 18 e 29 anos, que conviviam com os filhos. Para a coleta de dados foram utilizados um formulário online de inscrição, produção de fotografias sobre o cotidiano, e uma entrevista individual semiestruturada. Todos os 
diálogos que emergiram no trabalho de campo foram gravados e, posteriormente, submetidos ao processo de transcrição na íntegra, com a interpretação dos mesmos sendo realizada através da análise de conteúdo temática de Bardin. Os resultados obtidos demonstram a importância de rede de apoio para que os jovens consigam lidar com as demandas da paternidade/maternidade e acadêmicas. Além disso, foi demonstrada a importância do oferecimento de apoio institucional da universidade, principalmente com vaga em creches de universidades, para os filhos de todos os alunos.

Palavras-chave: Universidade; Pais; Relações Pais-Filho

\begin{abstract}
The lives of university students that have children is very complex, by uniting both of the process with very specific demands that are very hard to be reconciled, however, many young students go through this situation and deal with it in as many ways as possible according to their priorities. It's noticeable that factors like gender and a support network could make a difference in how those experiences happen, somehow dictating the quantity of responsibilities and the autoperception of these people as both students and parents. The research was conducted with a qualitative and cross-sectional method with four undergraduate students from a university in the interior of the São Paulo state, with ages between 18 and 29 years, that are parents and have the custody, even if shared, of their children. The data collection was made with an online application and a socio-economics form, the production of daily lives photographic records and an individual interview semi-structure. All the dialogues that emerge from the field study were recorded in a digital format and subsequently submitted to the process of full transcription, with the interpretation of those being made through the analysis of Bardin's content. The results obtained show the importance of a support network for young people to cope with the difficulties faced, both at university and as parents. Besides, the importance of providing institutional support from the university, especially as a place in university day care, for the children of all students was established.
\end{abstract}

Keywords: University; Parents; Parents-Children Relationship

\title{
Resumen
}

La experiencia de los estudiantes universitarios quien tiene hijos es muy complejo uniendo dos procesos con demandas especificas y muy dificiles de conciliar, sin embargo, muchos jóvenes atraviesan esta situación y la abordan de diferentes maneras según sus prioridades. Puedes ver que algunos factore como el género y la red de apoyo, cambian la forma en que ocurre la experiencia, de una manera que dicta la cantidad de responsabilidad y autopercepción de las personas como estudiantes y como padres. Sobre la base de estos factore, el objetivo de esta investigación fue comprender las experiencias y participación como padres de los estudiantes universitarios de graduación que tienen hijos. La investigación se realizó de maneira cualitativa y transversal, com cuatro estudiantes de una universidad en el interior del estado de São Paulo, de entre 18 y 29 años, que son padres y madres y tienen la custodia, aunque sea compartida, de sus hijos. Para la recopilación de los datos, un formulario de solicitud en línea y otra producción socioeconómica, producción de fotografias sobre su vida cotidiana y una entrevista individual semiestructurada. Todos los diálogos que surgen en el trabajo de campo ellos se registraron en dispositivo electrónico y posteriormente sometidos al proceso de la transcripción en su totalidad, con su interpretación realizada a través del análisis de contenido de Bardin. Los resultados obtenidos demuestran aunque la importancia de uma red de apoyo para que los jóvenes puedan hacer frente a las dificultades que enfrentan, tanto en la universidad como en los padres. Además, se demostró la importancia de proporcionar apoyo institucional desde la universidad, especialmente como un lugar en la guardería universitaria, para los hijos de todos los estudiantes.

Palabras clave: Universidad, padres, relaciones padre-hijo 


\section{Introdução}

Ser mãe ou pai é um processo complexo, que demanda tempo e dedicação, o qual pode levar a complicações em circunstâncias nas quais os pais têm que dividir o seu tempo com outras demandas que também exigem tempo e dedicação, como, por exemplo, os estudos universitários. Por conta disso, tais realidades são muitas vezes vistas como inconciliáveis, uma vez que se espera socialmente que os jovens da atualidade tenham uma longa jornada de escolarização e que os mesmos utilizem de estratégias contraceptivas adequadas (Peres \& Heilborn, 2006), e também que as mulheres do meio acadêmico sejam solteiras e jovens, alcançando o êxito em suas carreiras ao abandonarem seus "destinos" como mães, devido à dificuldade de conciliação dos estudos e da maternidade (Terra, 2019). Entretanto, há um número considerável de mães e pais que seguem na vida acadêmica, os quais são invisibilizados em sua condição tão singular.

A maternidade durante a graduação costuma ser vista pelas próprias jovens mães como um complicador, impactando nas mais variadas áreas de suas vidas, uma vez que as mesmas se consideram muito novas para tal responsabilidade, usualmente não planejada, e que geralmente é vivenciada em ambivalência: ora vista como positiva, ora como negativa. Tais mulheres podem sentir emoções conflitantes ao descobrir a gravidez, como medo e felicidade, abalo psicológico e alegria (Urpia \& Sampaio, 2011). Para lidar com sua nova condição, essas jovens podem recorrer a ferramentas como a espiritualidade e ressignificação de suas vidas, focando no lado positivo e encarando seus filhos como fonte de motivação e força (Manalang, Liongson \& Bayubay, 2015).

Entretanto, a tarefa de conciliar ambos os papéis - mães e estudantes -, ainda competem entre si, especialmente quando há ausência de apoio do companheiro (Sousa Melo et al, 2018) e da família, o que se mostra uma realidade recorrente (Mesquita et al, 2019). São demandas da universidade de um lado, como provas, trabalhos e estágios, e da maternidade do outro, como alimentar, cuidar e brincar com o filho (Urpia \& Sampaio, 2011). Tais conflitos podem levar a queda no rendimento acadêmico e embates em sua vida pessoal, na qual a mulher se vê obrigada a faltar de aulas para cuidar do bebê, incapazes de cumprir suas obrigações com seus parceiros e de construir laços com seus filhos (Manalang, Liongson \& Bayubay, 2015). Dessa forma, a sensação de não se sair integralmente bem em nenhum dos dois papéis é uma realidade, aliada à confusão e reconstrução de identidade dessas jovens, que agora, além de estudantes, são mães (Urpia \& Sampaio, 2011). 
Sentimento de culpa, dificuldades financeiras, restrições e isolamento social são outras consequências negativas de ser pai ou mãe na juventude (Urpia \& Sampaio, 2011). Além disso, tais jovens são estigmatizados pela sociedade, sendo vistos de forma negativa e preconceituosa - especialmente se há estereótipos de raça e classe envolvidos (Smithbattle, 2007). Ademais, boa parte das mães no ambiente universitário são solteiras (Fonaprace, 2016), o que é visto com maus olhos por boa parcela da sociedade, devido à presunção de uma gravidez fora do contexto marital (Terra, 2019). Esses estigmas colocados pela sociedade também estão relacionados a evasão escolar de mães adolescentes, uma vez que se associam à discriminação, e, por consequência, desajuste no meio escolar, onde esses indivíduos sentem que precisam fazer mais que seus colegas para serem aceitos (Hirst, Formby \& Owen, 2006). Sendo assim, julgamentos sociais, políticos e morais tendem a reforçar os inúmeros conflitos dessa vivência, além de gerar novos, rotulando as jovens por conta da gravidez, vista como precoce (Manalang, Liongson \& Bayubay, 2015).

Entretanto, existem outros fatores que podem influenciar nessa vivência. Jovens, especialmente homens, que experienciaram o crescimento de forma positiva e tiveram relacionamentos fortes com seus pais, encontraram mais confiança em sua habilidade para cuidar de seus filhos, aumentando assim o comprometimento e envolvimento na experiência parental. Marcadores de gênero também podem modificar a experiência, uma vez que se considera que mulheres tendem a ser mais atenciosas e promover maior conforto para seus filhos do que homens - diferenças que, em conjunto com outras, impactam na autopercepção desses indivíduos como pais e mães (Kershaw et al, 2015).

Considerando a realidade da sociedade atual que coloca como responsabilidade praticamente exclusiva da mulher cuidar e educar os filhos (Walsh, 2016), são inúmeras as dificuldades existentes na vida de mulheres que são mães, tornando a permanência no meio universitário um desafio para as mesmas - o que, de forma geral, não acontece com os homens (Mesquita et al, 2019). Por conta disso, não é incomum que mulheres optem pelo aborto ou encontrem dificuldades para seguir com suas vidas em ambos os papéis (Urpia \& Sampaio, 2011). Ainda assim, a educação é tida como prioridade por essas mulheres, pelo potencial de conseguirem empregos de qualidade no futuro e outras oportunidades. Tal percepção faz com que essas mulheres optem por continuar a estudar, mesmo sendo agora mães (Manalang, Liongson \& Bayubay, 2015). 
Vale destacar que dados do Censo 2000 mostram que cerca de $8,81 \%$ das mulheres no ensino superior, de 19 a 29 anos, possuem filhos de 0 a 4 anos. Esses números demonstram o quão recorrente é essa realidade, e o quão necessárias são políticas públicas que facilitem a formação dessas mulheres, possibilitando um futuro e carreira profissional de qualidade (Urpia \& Sampaio, 2011).

Ademais, Vieira et al (2019) destacam que há poucos estudos que investigam os desafios enfrentados por estudantes universitárias que engravidam no decorrer da graduação e, acrescente-se, menos ainda de estudantes que suas parceiras engravidaram nesse período. Assim, o presente estudo tem como objetivo compreender as vivências e o envolvimento parental de jovens universitários e universitárias da graduação com filhos, buscando compreender as implicações e a conciliação da condição parental com a vivência universitária e identificar se há apoio institucional para esses pais.

\section{Método}

A pesquisa foi realizada em período transversal e com a abordagem qualitativa. Essa escolha foi baseada nas quatro bases teóricas apresentadas por Flick, von Kardorff e Steinke (2000): a) a realidade social é vista como construção e atribuição social de significados; b) a ênfase no caráter processual e na reflexão; c) as condições "objetivas" de vida tornam-se relevantes por meio de significados subjetivos; d) o caráter comunicativo da realidade social permite que o refazer do processo de construção das realidades sociais torne-se ponto de partida da pesquisa.

\section{Participantes}

A pesquisa foi realizada com 4 estudantes de graduação de uma universidade pública no interior do estado de São Paulo, sendo dois do gênero feminino e dois do masculino. A quantidade de participantes foi decorrente do número de participantes que se encaixaram nos critérios de inclusão durante o período de recrutamento dos participantes.

Os critérios de inclusão da amostra foram: 1) serem estudantes de graduação da universidade em questão 2) se voluntariar por meio online ou presencial a participar da pesquisa; 2) ter o filho residindo com eles (assim tendo a guarda dos filhos, mesmo que de forma compartilhada); e 3) ter disponibilidade para entrevistas presenciais. 
A Tabela 1, a seguir, apresenta dados de caracterização dos participantes. Cumpre destacar que todos os nomes são fictícios de modo a não identificar o participante, seu/sua companheiro(a) e filhos(as).

Tabela 1.

Caracterização dos participantes

\begin{tabular}{|c|c|c|c|c|c|c|c|}
\hline Nome & Idade & $\begin{array}{l}\text { Idade } \\
\text { filho(a) }\end{array}$ & $\begin{array}{l}\text { Nome } \\
\text { filho(s) }\end{array}$ & $\begin{array}{l}\text { Sexo do(a) } \\
\text { filho(a) }\end{array}$ & $\begin{array}{l}\text { Status de } \\
\text { relacionamento }\end{array}$ & $\begin{array}{l}\text { Nome ex/ } \\
\text { parceiro(a) }\end{array}$ & $\begin{array}{l}\text { Área do } \\
\text { curso }\end{array}$ \\
\hline Ana & 22 & $\begin{array}{l}2 \text { anos e } 11 \\
\text { meses }\end{array}$ & Maria & Feminino & Casada & Vinícius & Exatas \\
\hline Beatriz & 25 & 6 meses & Joana & Feminino & União estável & Pedro & Exatas \\
\hline Carlos & 23 & 1 ano & Clara & Feminino & Solteiro & Amanda & Biológica \\
\hline Mateus & 29 & $\begin{array}{l}5 \text { anos } \\
3 \text { anos }\end{array}$ & $\begin{array}{l}\text { Flor } \\
\text { Lucas }\end{array}$ & $\begin{array}{l}\text { Feminino } \\
\text { Masculino }\end{array}$ & União estável & Luciana & Humanas \\
\hline
\end{tabular}

A Tabela 1, a seguir, apresenta dados de caracterização dos participantes. Cumpre destacar que todos os nomes são fíctícios de modo a não identificar o participante, seu/sua companheiro(a) e filhos(as).

\section{Procedimentos}

Para a coleta de dados foram empregados três procedimentos: 1) Formulário de inscrição; 2) Produção de fotografias sobre o cotidiano; e 3) Entrevista individual semiestruturada.

Para recrutar os participantes, um convite foi elaborado e divulgado em grupos de universitários em redes sociais e no informativo institucional o qual é enviado por e-mail para todos os campi da universidade. Esse convite apresentava os objetivos da pesquisa, critério de inclusão e o procedimento de coleta de dados. Além disso, continha um link de acesso para o formulário de inscrição, com a função de coletar os dados de identificação dos voluntários, e identificar se os mesmos se encaixavam nos critérios elegíveis para a coleta de dados.

Após a identificação de participantes que atendessem os critérios de inclusão, as pesquisadoras entraram em contato com os participantes para agendar um horário para realizar a entrevista presencial. Nesse momento, os participantes também eram instruídos para que, ao longo da semana, produzissem fotos do seu cotidiano, com foco na universidade e nos filhos, as quais seriam solicitadas durante a entrevista. 
E por fim, houve a realização de uma entrevista de forma individual e presencial a qual ocorreu em duas etapas: (1) métodos visuais e (2) aplicação de um roteiro de entrevista semiestruturada, elaborado para a presente pesquisa pelas autoras com base na literatura da área e objetivos do estudo, e estruturado a partir das temáticas: 1) conciliação da vida acadêmica e como pais; 2) autopercepção; 3) relação com os filhos; e 4) rede de apoio. Para analisar a rede de apoio, foram usadas questões baseadas no Mapa dos Cinco Campos (adaptado de Dell'aglio \& Siqueira, 2012), em que cada campo compõe um aspecto da vida em que se percebem fontes de apoio, tendo em vista o círculo do meio que representa a própria pessoa. Para a presente pesquisa, os participantes eram solicitados a identificar em quais aspectos da vida (família, parentes, contatos formais, universidade e amigos) eles identificam que recebiam maior suporte.

Assim, a primeira etapa da entrevista se apoiou nos métodos visuais, fundamentado na proposta de Harper (2002). Esse método se utiliza da reflexão dos participantes a partir de representações visuais que são compartilhadas por eles mesmos, eles próprios dando os significados e motivos para a escolha de tais fotos. A técnica foi escolhida por inspiração no trabalho de Liebenberg (2009), no qual a pesquisadora pediu para participantes de um estudo produzirem imagens fotográficas do seu cotidiano. Posteriormente, com essas imagens produzidas, foram feitas entrevistas individuais a partir de questões abertas relacionadas às fotos, possibilitando a reflexão das participantes e da pesquisadora. Diferente da pesquisa de Liebenberg, que utilizou câmeras descartáveis, na presente pesquisa houve o uso de celulares, pois trata-se de um recurso que estava presente no cotidiano da maioria dos participantes. Os participantes encaminharam as fotos para as pesquisadoras por meio de um aplicativo de mensagem.

Já na segunda etapa, os participantes responderam a questões abertas do roteiro de entrevista semiestruturado com o objetivo obter dados sobre a experiência de maternidade/paternidade, desde a descoberta da gestação até o momento da pesquisa, e sobre o cotidiano dos participantes como pais e universitários, tanto questões de estudo quanto de lazer. As entrevistas foram gravadas em áudio, com autorização dos participantes e tiveram duração de cerca de uma hora.

Cumpre destacar que foram tomados os devidos cuidados para que, antes de dar início à coleta de dados, fosse estabelecido um ambiente acolhedor e o vínculo entre a pesquisadora e participantes, visto que se tratam de perguntas que podem trazer conteúdos com forte carga afetiva. Vale ressaltar que a entrevista não acabou de uma maneira 
abrupta, sendo as perguntas finais mais relacionadas a conteúdos positivos e que geram bem-estar.

\section{Análise de dados}

A interpretação dos dados foi realizada através da análise de conteúdo, proposta por Bardin (2009), que divide a análise em três fases: a pré-análise, a exploração do material e o tratamento dos resultados. Na primeira fase, designada como pré-análise, o material foi organizado, e, a partir da transcrição das entrevistas, foi realizada uma leitura de todos os dados. Na segunda fase os dados foram codificados, isto é, foram divididos em temas ou palavras chaves que sintetizassem semanticamente trechos manifestados pelos participantes. Nessa fase da análise, foi utilizado o software Atlas.ti. Durante o processo de codificação, as pesquisadoras buscaram entrar em consenso quanto às unidades de análise (códigos) a serem utilizados. Já na terceira fase, a literatura publicada sobre o assunto foi retomada, buscando o significado dos conteúdos evocados pelos participantes e que podem dar indicadores sobre temáticas analíticas.

\section{Aspectos éticos}

O projeto foi submetido à aprovação do Comitê de Ética em Pesquisa com Seres Humanos, CAAE: 15746819.1.0000.5504. Os participantes da pesquisa assinaram o Termo de Consentimento Livre e Esclarecido, após ler e apresentar concordância com todos os itens. Os vocábulos utilizados nesses documentos, assim como as expressões empregadas nas conversas de apresentação da proposta, levaram em consideração os recursos cognitivos das participantes.

\section{Resultados}

No total foram elaborados 13 códigos (Apoio; Creche; Desempenho acadêmico; Família; Gênero; Gravidez; Motivação; Parceiro; Renda/questões financeiras; Rotina/tempo livre; Sugestões; Vida social; Visão do futuro), relacionados diretamente às temáticas das perguntas, por esse motivo, todos os participantes relataram o código pelo menos uma vez. Em seguida, as pesquisadoras analisaram os códigos que haviam sido gerados e organizaram os mesmos em categorias mais amplas de análise $(n=7)$. A Tabela 2 apresenta as categorias elaboradas, os códigos pertencentes a cada uma e o número de citações. 
Tabela 2 .

Descrição das categorias, códigos e número de citações

\begin{tabular}{|c|c|c|}
\hline Categorias & Códigos & $\begin{array}{l}\text { Quantidade de vezes que } \\
\text { apareceram nos discursos }\end{array}$ \\
\hline Universidade & $\begin{array}{l}\text { Rotina; Desempenho Acadêmico; } \\
\text { Creche; Universidade. }\end{array}$ & 120 \\
\hline Apoio & Família; Parceiro; Creche; Apoio. & 95 \\
\hline Dificuldades & $\begin{array}{c}\text { Gravidez; Renda; Questões } \\
\text { Financeiras. }\end{array}$ & 52 \\
\hline Rotina/Tempo Livre & $\begin{array}{c}\text { Rotina; Tempo Livre; Vida } \\
\text { Social }\end{array}$ & 47 \\
\hline Gênero & Gênero. & 35 \\
\hline Motivações & Motivações; Visão de Futuro. & 9 \\
\hline Sugestões & Sugestões. & 4 \\
\hline
\end{tabular}

Como pode ser visto na Tabela 2, houve uma frequência maior de relatos dos participantes relativos à universidade, apoios sociais e institucionais e dificuldades. A seguir serão apresentados os dados organizados de acordo com as categorias pertinentes, a saber: (1) universidade; (2) rede de apoio; (3) dificuldades; (4) rotina/tempo livre; (5) vida social; (6) motivação; (7) gênero e (8) sugestões.

\section{Universidade}

Sendo uma das temáticas que mais apareceram nos discursos devido a relação dos participantes com a mesma, a universidade foi abordada sobre os mais diversos aspectos, seja em relação aos professores, colegas, desempenho nas avaliações, seja no que se refere à infraestrutura, ambiente e, principalmente, à creche presente dentro na mesma.

Ao falar sobre a relação com os professores os participantes relataram considerar muito importante o apoio e compreensão destes a respeito das particularidades de ser pai/mãe e estudante:

A vez que a Maria (filha) ficou doente um professor meu aceitou o atestado dela, entendeu. Então assim, foi muito legal (...). Ela (professora) tá super tranquila, não tá cobrando muito pra não sobrecarregar também uma rotina que já tá corrida. (Ana). 
E meus professores também são de certa forma acolhedores. Eles entendem que não dá pra eu ficar na aula assim e às vezes eu fico mais fora da aula, na porta, do que dentro da sala de aula. (Beatriz).

Contudo, um dos participantes, Carlos, diferiu dos demais, dizendo que nem todos os professores compreendem sua situação como pai, conforme é possível identificar em seu relato:

Então alguns professores não tem essa empatia, sabem que eu sou pai e tal. Eu também não fico usando isso como desculpa toda hora, mas eu sei que a condição é essa. Então alguns professores e professoras, eles não têm essa sensibilidade. Outros têm. Mas outros não tem. (Carlos).

Assim, fica claro que os participantes avaliam como positiva a compreensão e empatia que certos professores têm em relação a suas dificuldades em conciliar a vida como pais e mães e como universitários, e que a ausência da mesma se configura como um dificultador.

Chama a atenção o fato de um participante do gênero masculino relatar que alguns professores não tem sensibilidade em relação a sua condição de pai. Nesse sentido, parece haver um viés de gênero em relação a compreensão dos professores e o gênero do estudante, com as mãe tendo uma percepção maior de apoio do que os pais, o que pode estar relacionado com os estereótipos de gênero conjunto de crenças, individuais ou partilhadas, acerca dos atributos pessoais adequados para homens e mulheres (D’Amorim, 1997) -, relacionados à concepção de que os homens devem ser provedores econômicos da família e as mulheres com a responsabilidade unilateral de cuidadora do lar, dos filhos e do marido e responsável pelo bom funcionamento familiar e desenvolvimento infantil sadio (Walsh, 2016; Mesquita et al, 2019). Logo, ao se considerar que a mãe deve dedicarse integralmente aos filhos (Narvaz \& Koller, 2006), tornando-a como figura insubstituível para o bem-estar infantil, assumindo um papel de maior relevância quando comparado à paternidade (Botton et al, 2015; Walsh, 2016), tal atitude do professor parece justificada ao desconsiderar as necessidades do pai.

No que diz respeito ao relacionamento com os colegas de sala, por outro lado, a maternidade/paternidade dificultou as relações para parte dos participantes, causando distanciamento dos mesmos, conforme pode-se notar no discurso de Ana: "Então muitas vezes eu acabo não batendo muito papo, tudo, com os colegas por causa mesmo dessa agitação do dia a dia”. Tal características também são 
encontradas na fala de Beatriz, que diz: "E agora parece que afastou ainda mais, entendeu? Até porque a gente não tem como ficar se reunindo, que o pessoal sai bastante. A gente não tem esse tempo. Então dos professores me surpreendeu. Em relação aos colegas é que me decepciona um pouco".

$\mathrm{O}$ afastamento por conta da rotina muito diferente torna-se um complicador para encontrar apoio entre os colegas de sala e fazer atividades em grupo, conforme Beatriz também declarou:

E por exemplo: eu descobri semana passada que (...) a professora falou "Gente, vai ter prova semana que vem. Os grupos podem vir apresentar" E eu falei "Os grupos? Como assim os grupos?" Todo mundo tinha grupo, menos eu e o Pedro (parceiro). A gente ficou bem excluído. (Beatriz).

Em uma pesquisa realizada com 20 mães primíparas para identificar os impactos da maternidade nos papéis ocupacionais, Behar (2018) verificou que as mães tendiam a deixar de lado o convívio social para priorizar os momentos de cuidado com seu filho. Tal prioridade pode ser decorrente das próprias demandas do(a) filho(a), pela necessidade de envolvimento afetivo da mãe ou pela indisponibilidade de pessoas para substituí-la nessa tarefa. Consequentemente, observa-se uma mudança no envolvimento com pessoas externas ao ambiente familiar, o que pode acarretar em prejuízos nas relações de amizade, de trabalho e até mesmo em costumes e rituais que outrora eram significativos para ela.

Convergindo com Behar (2018), os dados obtidos por Cardoso (2017) com quatro mães adolescentes (16-19 anos) recrutadas em uma Escola Móvel numa Instituição de apoio a Mães, em Lisboa, demonstraram que as participantes relataram mudanças nas relações de amizade, tanto em relação à proximidade física quanto a quantidade de tempo de convívio.

Quando perguntados sobre o desempenho acadêmico, todos os participantes declararam que este melhorou após terem filhos, ao contrário do que indica a literatura, a qual conclui que as obrigações da universidade, tal como provas e estágios, e as obrigações relacionadas aos cuidados com o filho entram em conflito, como acontece em situações onde a mãe é forçada a faltar das aulas para cuidar do bebê, fazendo com que o rendimento acadêmico das mesmas seja diminuído (Manalang, Liongson \& Bayubay, 2015), ou então pela falta de apoio institucional, com a falta de creches universitárias, programas de apoio e horários rígidos (Vieira et al, 2019). Carlos, por exemplo, afirmou: "O maior desempenho foi no ano que a 
minha filha nasceu (...) eu já sabia que ela viria, que ia ser muito difícil. Então me dediquei ao máximo assim, pra ser o mais excelente possível naquele semestre. Depois que ela nasceu eu peguei menos disciplinas".

Outro participante, Mateus, fez uma declaração parecida:

$\mathrm{Eu}$ percebo que geralmente o desempenho acadêmico tende a ficar pior né, quando tem filho, uma criança no meio da graduação. Mas no meu caso na verdade melhorou, porque eu tinha um desempenho muito ruim, tinha muita disciplina que eu não conseguia ser aprovado. E depois das crianças meu aproveitamento melhorou muito (...) acho que pela pressão, necessidade, e também porque eu fiquei mais preocupado em não perder o auxílio do programa de assistência estudantil. Eu não podia perder, agora com criança e tal, e antes eu não dava muita importância pra isso. (Mateus).

A melhoria do desempenho acadêmico se dá, como pode-se notar pelas declarações, pela noção de que a vida com um filho precisa de garantias e estabilidade e que a faculdade, sendo uma forma de garantir um bom futuro e condições para os filhos, precisa ser aproveitada. Outro fator, além deste, é a compreensão de que a conciliação da universidade e da maternidade é difícil demais para ser prolongada por conta de reprovações, conforme declara Ana: "E eu acho que estou mais empenhada (...) porque não dá pra reprovar, não dá pra pensar em mais um ano (...) ficar mais um ano é mais instabilidade".

Ainda que o desempenho acadêmico tenha melhorado, os participantes ressaltaram mais de uma vez o quanto precisaram se reorganizar para conseguir cumprir todas as demandas da universidade, lidar com imprevistos e dar atenção para o filho, conforme Carlos relatou:

Mudou na questão de lidar com tempo. Então o tempo é menor pras coisas, porque tem o tempo com ela. Ai não tem como tirar o tempo com ela, né? Então tem o tempo com ela, que tem que ter um aproveitamento maior do tempo, de fazer as atividades. Em algumas coisas eu consegui progredir, outras não. De fazer as vezes uma atividade um pouco mais rápido, mas de uma forma boa do que ficar às vezes divagando muito, procrastinando. A procrastinação diminuiu (...). Então tem o limite de falta (de aulas) e eu não vou faltar por qualquer coisa. Então eu utilizo as faltas sabendo que eu vou ter que faltar em algum momento pra ficar com ela. Sempre atento, consulta médica, pra levar no pediatra, ou ela doente mesmo (...). Apago o compromisso que eu tenho de ir pra aula. (Carlos).

No que diz respeito à infraestrutura e acessibilidade da universidade, a mobilidade foi o fator mais marcante trazido pelos participantes. Ana, uma 
participante que não possui vaga em creche para sua filha, tendo, portanto, que levála para todos os lugares consigo, foi a que mais demonstrou tal dificuldade:

Que querendo ou não aqui é muito subida, descida, subida, descida. Não é acessível. Ainda que você tenha um carrinho, a maioria aqui é escada e as ruas não são lisas. As calçadas não são lisas (...). Até certo ponto beleza, mas depois pra ir pro RU (Restaurante Universitário), sem condições. É muito difícil. Então acho que ser um pouco mais acessível também facilitaria muito. (...) Eu tinha um carrinho no começo, e na segunda semana quebrou. Ainda aqui na (área) sul é um pouquinho melhor, mas lá pra área norte é péssimo. (Ana).

Além disso, por ter que levar a filha para todos os lugares da universidade para onde vai, juntamente com seu material de estudos, não ter mais um carrinho de bebê e não ter um carro, Ana desenvolveu condições físicas como a tendinite, o que demonstra o quão sério é questão da mobilidade para aqueles que possuem filhos.

De forma geral, os participantes declararam que a universidade como um todo não é um local receptivo para os pais, e tão pouco para os filhos, contando com a ausência de trocadores nos banheiros, locais de lazer e brincadeira para as crianças e, como já dito anteriormente, pouca acessibilidade. Os únicos locais que foram tidos como adequados foram: um espaço infantil presente na biblioteca da universidade e escola de educação infantil dentro da instituição. No depoimento de Mateus, ele explica que tentou articular mudanças no ambiente em conjunto com um grupo de pais:

Mas o grupo tinha pautas que discutia com a gestão da universidade para que realmente fosse um espaço acolhedor pras crianças, para garantir mais ainda a permanência estudantil. A principal pauta nossa seria criar um espaço (...) para crianças dentro da universidade além da creche - pra quando tivesse fechada, ou se o estudante não tem vaga na creche - que seria um espaço de convivência focado nas crianças mesmo. Mas (a gente) ficou uns dois anos tentando encontrar esse espaço dentro da universidade, e tem várias burocracias. Agora ficou bem empacado. Antes a gente tava discutindo quase toda semana, mas agora tá parado. (Mateus).

A creche presente dentro da universidade foi um assunto recorrente no discurso de todos os participantes. Essa creche se encaixa no contexto de luta desde a década de 1970 para a criação de Unidades Universitárias de Educação Infantil (UUEI), em universidades públicas federais, para que os filhos de alunos e funcionários pudessem permanecer (TX1). A creche também é umas das áreas de ação previsto pelo PNAES (Plano Nacional de Assistência Estudantil), plano que 
busca apoiar a permanência de estudantes de baixa renda em instituições de ensino federais. No entanto, por conta da falta de recursos, a criação das creches não fica em primeiro plano (Tomazi et al, 2016). Assim, aqueles que possuem vaga para deixar seus filhos a avaliaram como essencial para manter a vida em ordem, conciliando estudos, maternidade/paternidade e demais demandas rotineiras, o que indica esse serviço como um importante elemento na rede de apoio desse pais/mães estudantes.

E também tem a creche, que eu acho que auxilia bastante os pais. Não é a toda universidade que tem escolinha, ainda mais uma escolinha tão boa. E eu acho que eu me sinto apoiada pela universidade, sinto que tem um respaldo pela questão de ser mãe, sabe? Sinto que eles também me ajudam um pouco (...). Pra mim eu nunca precisei trazer minha filha pra aula, eu sempre consegui a creche ligada à universidade. (Ana).

Porque a rotina ia ser diferente sem a creche, pública ou particular. A gente ia tentar colocar numa pública, mas se não fosse possível e tivesse que colocar numa particular ia ter toda essa coisa do dinheiro pra colocar ela lá, dos materiais, da comida. E aqui, ela tem um certo privilégio porque não são muitas crianças. São muitas pessoas de apoio que são os estagiários da universidade, e tem a alimentação que eles dão lá, além de todas as atividades que são muito legais pra eles. Então é um lugar perfeito. (Carlos).

Mas, conforme os próprios participantes que usufruem da creche ligada à universidade mesmos reconheceram em suas falas, a creche não é para todos. A única participante que não possui a vaga foi a que demonstrou maior cansaço e desgaste por conta de ter que levar a filha para as aulas, estágio e demais afazeres, deixando claro inúmeras vezes o quanto sente falta da creche, e que mesmo que tenha tentado colocar sua filha lá mais de uma vez, não obteve sucesso - ao ponto que condições financeiras a impedem de matricular a filha em alguma instituição de educação infantil.

Por exemplo a creche: o ano passado ainda tava grávida, não podia me inscrever no edital porque ela ainda não tinha nascido. Beleza. Aí esse ano, desde que quando eu voltei eu tô vindo, conversando. Por exemplo: eu não sei exatamente o que aconteceu, que agora ela atende a comunidade externa. É sorteio, não tem preferência nenhuma. A única preferência que tem é bolsistas permanência - ou alimentação ou moradia. Eu não tenho nenhuma"; "Uma coisa que me ajudaria muito assim, seria a creche. Acho que assim, de financeiro, eu acho que nem tem com a gente ter essa... Vontade (...). Mas o que me ajudaria muito é por exemplo a creche, porque você consegue assistir a aula, de ficar (na sala) realmente. (Beatriz). 
Dessa forma, nota-se que, ainda que limitado, o suporte que a universidade fornece por meio da creche é um fator decisivo para a rotina dos participantes, visto que ter um local adequado onde deixar seus filhos durante o período de aulas e estágio, favorece o engajamento dos mesmos nas atividades acadêmicas, constituindo-se em um importante elemento da rede de apoio e um mecanismo de auxílio para a terceirização do cuidado com o filho(a) (Behar, 2018). Contudo, ainda há a necessidade de adequação de espaços no campus que permitam a acessibilidade (por exemplo, rampas, calçadas etc.) e permanência dos estudantes pais/mães nesses contextos. Em relação aos docentes, destaca-se o papel dos mesmos em compreender a realidade vivenciada pelos estudantes pais/mães, flexibilizando prazos de entrega de trabalho, frequência às aulas e atividades.

\section{Rede de apoio}

A partir de uma perspectiva bioecológica do desenvolvimento (Bronfrenbrenner, 1979/1996), as relações que uma pessoa estabelece ao longo do seu ciclo vital podem influenciar de forma significativa, tanto positiva quanto negativamente, a definição da sua personalidade e o seu desenvolvimento (Juliano $\&$ Yunes, 2014). Nesse sentido, torna-se relevante analisar a rede de apoio social dos participantes, compreendida como um conjunto de sistemas e pessoas significativas, as quais compõem os elos de relacionamento recebidos e percebidos do indivíduo (Brito \& Koller, 1999). De acordo com Rapopport e Piccinini (2006), o apoio social é muito importante em períodos potencialmente estressantes como, por exemplo, quando a mãe precisa cuidar do seu filho e realizar as tarefas domésticas, assim como , no caso da presente pesquisa, quando ela tem que realizar as atividades acadêmicas.

Vale destacar que a rede de apoio social consiste em um construto multidimensional (Gabardo-Martins, Ferreira \& Valentini, 2017) que está relacionado à percepção que o indivíduo tem a respeito de pessoas e sistemas capazes de proporcionar conforto, afeto, acolhimento, informações e até mesmo recursos financeiros (Rapopport \& Piccinini, 2006), estando também relacionado com as estratégias para estabelecer vínculos, os recursos que lhe são oferecidos, bem como à proteção frente às situações de risco (Brito \& Koller, 1999). A rede de apoio social pode incluir a família extensa, os amigos, colegas de trabalho, relações comunitárias e serviços de saúde, de credo religioso ou político (Rapopport \& Piccinini, 2006). 
Visando favorecer a identificação da rede de apoio de cada um dos participantes, adaptou-se a aplicação do Mapa dos Cinco Campos (adaptado de Dell'aglio \& Siqueira, 2012). Para tanto, era apresentada a representação gráfica do mapa e solicitado que os participantes indicassem os apoios recebidos em cada um dos campos. Cumpre destacar que os participantes consideraram como família o(a) parceiro(a), pai/padrasto, mãe e sogros; parentes a família extensa (tios, primos, irmãos etc.), escola a universidade e, em um dos casos (Matheus), também como o local onde os filhos estudavam, e contatos formais a unidades de saúde (Ana), locais de estágio/trabalho (Matheus), programas de governo, incluindo também medidas da universidade (Beatriz) e serviços públicos (Carlos). A Figura 1 a seguir apresenta a avaliação dos participantes quanto ao apoio percebido e recebido.

Os dados apresentados na Figura 1 indicam que a família foi a fonte de apoio mais próxima aos participantes, como pode ser exemplificado no relato abaixo:

Bom, a família é minha filha, a minha mãe, meu padrasto, meu pai e meu irmão. São pessoas que me ajudam e que me dão um suporte financeiro, quando eu preciso. E são aquelas pessoas que ouvem meus problemas assim também. Alguns problemas que só eles entendem. Problemas que estão relacionados já a essa vida adulta de ser pai, trabalho. Então eles estão mais próximos de mim em função disso, que de fato eles me conhecem muito melhor e tal. Conhecem mais a minha realidade, meus problemas e tudo isso. (Carlos).

Ela (sogra) dá carona e tal. Que também se não fosse por isso ficaria muito inviável, porque são dois ônibus do meu bairro pra cá (universidade)"; "Mas no que ela pode me ajudar nos fins de semana, as vezes quando tem prova.... Tive um trabalho super grande semana passada e junto com várias coisas, então ela (sogra) ficou um pouco com ela (filha) a noite"; "Até porque a minha rede de apoio é minha sogra. (Beatriz). 


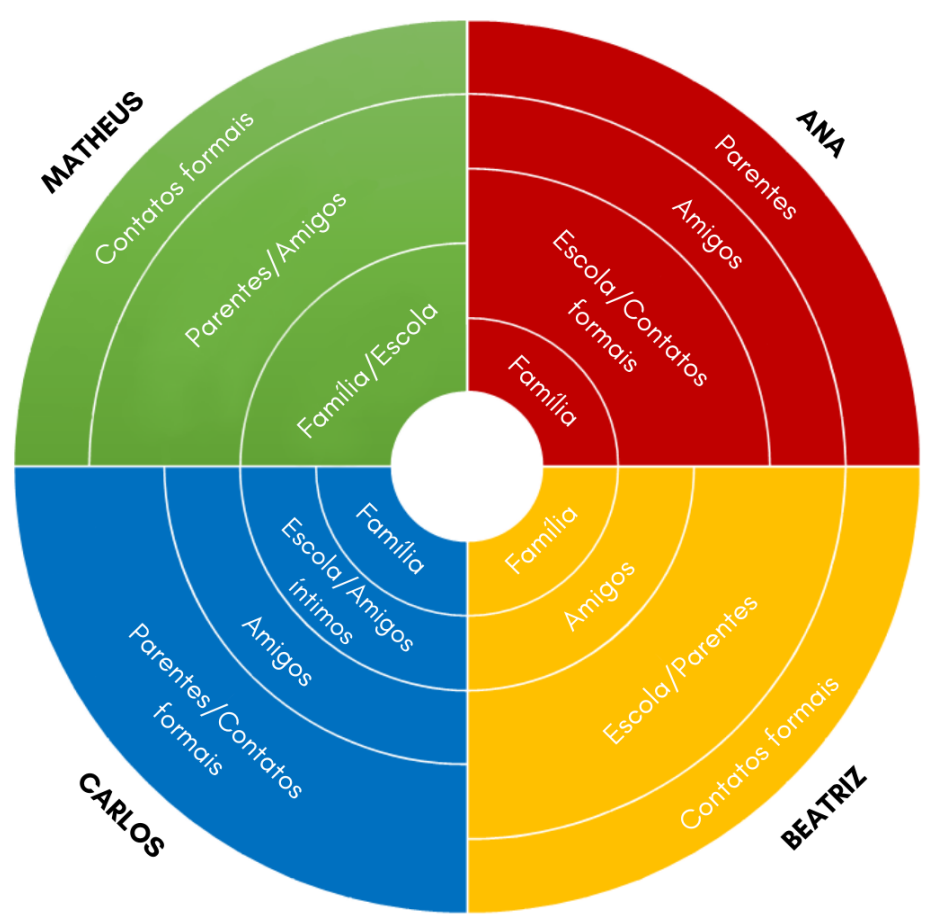

Figura 1.

Avaliação dos participantes quanto aos apoios percebidos e recebidos em diferentes esferas.

Os parceiros apareceram como figuras importantes para auxiliar no equilíbrio das demandas entre os cuidados com os filhos e as atividades acadêmicas:

Então ele ajuda bem, se adequou bem a rotina tudo. E ele adora ficar com ela, brincar com ela, me auxilia bastante. Tanto na questão financeira quanto psicológica, emocional. E ele me apoia muito na universidade. Quando eu passei aqui - eu sou muito de não querer sair da bolha sabe? Muito medo e ele "não, vamos que vai dar certo, a gente se esforça, e vamos que vai ser bom". Ele me incentiva muito nessa parte, tanto que quando eu preciso estudar ele fica com a Maria, ele não se importa. (Ana).

Inclusive quando o relacionamento foi rompido, como era o caso de Carlos: "Porque assim, eu tenho aula à noite e minha ex companheira também tem aula a noite, então a gente se reveza. No momento que ela tá em aula a noite, eu fico com a Clara".

Em relação aos parentes, ou seja, a família extensa, apenas Carlos relatou ter um apoio menor dos mesmos, devido a questões geográficas:

Os Parentes aqui, pensando nos parentes mais distantes, eles têm um certo contato comigo, mas não é tão próximo (...). Mas são parentes um pouco distantes. Tenho um tio em outro estado, as vezes manda uma graninha 
assim. Mas eles estão bem longe, assim. Sabem muito pouco da minha realidade aqui, diferente dos meus pais que moram mais perto, que já vieram aqui e tal. (Carlos).

Em relação à escola, aqui compreendida como a universidade na qual os participantes cursavam a graduação, os apoios percebidos/recebidos foram relacionados aos professores:

Então os professores foram me surpreendendo. Eles dizem tipo "não desiste, não para por aí. Força, vamos". Isso me surpreendeu muito nos professores. Eu tava com um medo danado, por conta de ter que levar ( $a$ filha) na aula. E eles são bem compreensivos. (Beatriz).

A faculdade eu acho que esse negócio de professor dar uma facilitada, entender a situação da gente, às vezes com uma presença, às vezes com uma nota, com um atraso de trabalho. Isso ajuda bastante, porque nem sempre eu consigo ficar dentro dos prazos. É bem difícil. (Beatriz).

Aqui na universidade sempre tive apoio. Sempre, até quando (eu) não tinha conseguido vaga na escola para minha filha, um professor meu falou que se eu ultrapassasse o número de faltas eu poderia entrar com recurso, por conta disso. (Ana).

E ao apoio financeiro para permanência estudantil:

No caso da universidade eu considero mais esse apoio financeiro das bolsas. A universidade que me proporciona ter as bolsas que eu tenho - de iniciação, do cursinho, a bolsa "pai" lá, a bolsa de aluguel e essas coisas pra poder sobreviver. Então tudo o que faz que eu seja um bom aluno e tal, tem a ver com os benefícios que a universidade me possibilita (...). A questão da universidade eu tô considerando o apoio financeiro e o apoio da escola infantil, que de certa forma está diretamente relacionado com a forma com que eu vivo atualmente, com os costumes que eu tenho. (Carlos).

Tais dados sinalizam a importância de os docentes estarem conscientes das necessidades de seus alunos relativas ao exercício da maternidade/paternidade, flexibilizando algumas das demandas para que eles consigam atender as expectativas acadêmicas. Ademais, destaca-se a relevância de suporte financeiro, a partir de programas de permanência estudantil, e da existência de escolas infantis com vagas para os filhos(as) dos alunos(as), embora os mesmos nem sempre sejam suficientes, como destacou Mateus:

Então é uma coisa que ajuda bem sim. Mas acho que não é suficiente. Tem gente que saiu mesmo com essa bolsa, acabou evadindo. A gente não tem números exatos, uma estimativa pelo menos de quantos estudantes com filhos abandonam (a universidade), mas não é um número baixo. (Mateus). 
Os amigos foi uma categoria que apareceu em diferentes lugares na percepção dos participantes, indicando as visões conflitantes sobre o apoio dos mesmos, pois ainda que forneçam apoio significativo, não podem compreender por completo sua vivência por, em muitos casos, não terem as mesmas demandas dos participantes, como pode ser visto nos relatos a seguir:

Os amigos, eu não coloquei assim tão próximo porque tem esse limite que eles não são pais, e tem uma outra coisa que eles não conhecem tão bem assim a minha história antes de vir pra cá, coisa que minha família conhecem. E eles não têm essa noção do... De tudo que eu... Eles sabem de tudo que eu tenho que fazer em casa e assim. Mas o suporte deles tem um certo limite, que não é um limite tão próximo assim igual ao da minha família, mas existe. Isso tanto de amigos que são próximos quanto de amigos que não são tão próximos assim, né? (Carlos).

E amigos também eu coloquei um pouco menos, porque quando você vira mãe tudo, muitas pessoas se afastam. Você para de ter um círculo social tão grande do que quando você tá nas festas. Então meus amigos diminuíram bastante. Mas eu sinto que os que eu tenho ali são os que eu posso contar de verdade, eles também me auxiliaram sem problemas. (Ana).

Os amigos infelizmente não entendem. Eu tenho dois amigos assim, que são meus amigos desde o ensino médio. E eu sinto que a gente meio que se afastou, até porque não dá mais pra sair. Quando eles vêm em casa, os horários deles é diferente dos nossos. Por exemplo: eles chegam em casa 21h. $21 \mathrm{~h}$ eu tô morrendo, já quero dormir. É que eu acordo muito cedo, independente se é sábado, domingo, terça, quarta. É todo dia muito cedo. Então dá aquela afastada. Não tem muito jeito. (Beatriz).

\section{Dificuldades}

Apesar da presença dos filhos na vida desses pais aparecer como algo positivo em seus discursos, e a universidade também ser descrita como um local que geraria oportunidades importantes, as dificuldades na vida desses jovens aparecem em diversos contextos.

O primeiro contexto que as dificuldades apareceram foi logo no começo da experiência como pais, ou seja, na gravidez. Nenhuma das gestações ocorreu de forma planejada, assim, medos e mudanças de planos foram geradas, como relatado por Ana: “A gente ficou noivo, passou umas semanas eu descobri que tava grávida. Aí eu achei que não fosse dar conta de fazer faculdade com criança, fosse algo impossível, aí eu saí da faculdade, tranquei a faculdade, fui embora pra minha cidade natal para ter a Maria (filha)". Ana na época estava com 18 anos e no seu primeiro curso de graduação, e sentiu a necessidade de trancar o curso para lidar com as 
questões da maternidade, questão que aparece em outros estudos com universitários, como o de Melo et al (2018). Ana relata também dificuldades advindas dessa escolha, por ficar "um ano parada em casa o dia todo", o que gerou sofrimento psíquico levando a um quadro de depressão.

A mudança de planos proveniente da gravidez também foi relatada por Mateus: Eu tinha 24 anos quando a gente soube que a Luciana tava grávida da Flor (filha), não era planejada, a gente tinha um relacionamento curto até, uns 3 meses juntos, estávamos apaixonados e tal, ela tava indo pro Ciências sem Fronteiras, foi pra Austrália. E ela foi sem saber que tava grávida. (Mateus).

A descoberta da gravidez gerou a reorganização dos planos do casal, com a escolha para que Luciana voltasse para o Brasil, para ter proximidade de Mateus e da família, e por questões de plano de saúde.

A questão financeira também foi relatada pelos participantes como algo que gera muitas preocupações. No momento da gravidez, a questão financeira se mostrou como dúvidas, como relatado por Carlos: "E daí a gente ficou muito apreensivo, assim na verdade. Principalmente na questão financeira, né? Como a gente ia conseguir lidar com tudo isso e tal". Já no momento após a gravidez, nota-se que para que se consigam uma renda que cubra seus gastos, os pais se desdobram em mais de um serviço, como, por exemplo, Mateus que relata trabalhar como motorista de aplicativo e como estagiário, além de vender hambúrgueres com a sua esposa, que também tem um outro emprego.

A preocupação com a renda estava também relacionada diretamente com o cuidado dos filhos, como alegado por Carlos: "Como pai eu acredito que eu tenho o dever de dar condições, ter um dinheiro para dar condições confortáveis para ela".

Além disso, parte dos participantes relatou a necessidade de receberem auxílio financeiro da universidade para complementar sua renda, como descrito por Ana: "Eu recebo a bolsa aqui da universidade, de baixa renda, e por causa de eu ser mãe essa bolsa tem um acréscimo”. No entanto, outro participante, Carlos, relata as preocupações advindas da bolsa, ou na verdade, do momento em que a mesma não mais existir: "Em algum momento essa bolsa vai acabar, tem um prazo. Então tem essa questão do trabalho, que preocupa muito a mãe dela e me preocupa também”.

A dificuldade relatada pelos pais também aparece na questão da rotina, tanto na universidade quanto em casa. Isso ocorre pelo fato de terem todos os afazeres da 
graduação, como aulas, provas e trabalhos, a necessidade de gerar renda por estágios e empregos, unidos com os cuidados da casa e dos filhos. Um dos pontos mais relatados por Ana foi quanto a sensação da falta de tempo, principalmente quando comparam sua situação com os outros colegas.

Então tem uma gama de coisas da minha rotina que eu dedico meu tempo pra isso porque é fundamental, não tenho outra pessoa que lava minha roupa, faça minha comida igual meus amigos tem. Então é uma condição que é completamente diferente (...) Alguns momentos eu me sinto um pouco estressado, mas não com minha filha, e sim com as coisas da universidade, e isso acaba me deixando um pouco impaciente, assim... Um pouco atordoado de às vezes não conseguir gerir o tempo - o tempo de estar com ela, de fazer algumas coisas assim. (Carlos).

Assim, as dificuldades desses pais unem nos mesmos sujeitos questões de parentalidade, de ser universitário e do que seria considerado da vida adulta, como questões financeiras, mostrando que mesmo as questões que eles veem de forma positiva, como os filhos e a universidade, também geram fatores de dificuldades em suas vidas.

\section{Rotina/tempo livre}

Ao analisar o dia a dia dos participantes, a conciliação das tarefas universitárias com o cuidado do filho aparece de forma consistente - mesmo em momentos de lazer ou tempo livre, o cuidar da criança se faz presente.

A universidade toma grande parte do dia dos participantes, enquanto outras tarefas como trabalhos e as atividades intrínsecas da maternidade/paternidade eram realizadas à noite, juntamente com tarefas domésticas. Beatriz, ao falar sobre sua rotina, afirmou: "E chego em casa, se não tem trabalho, tem filha. Se não tem a filha no geral, tem que dar um jeito na casa, se não..."; "É difícil esses minutos a noite que você tem tudo pra fazer". Assim, ela demonstra os desafios em conciliar tantas tarefas. Ao ser perguntada sobre quais fotos tiradas por ela ilustravam momentos difíceis, ela disse: "Eu acho que é minha foto estudando também, que é conciliar a vida num geral com ela (filha). Que é uma delícia, (ela) é o amor da minha vida, mas é cansativo".

Além disso, ela ressaltou o quão difícil era para ela estabelecer verdadeiramente uma rotina, uma vez que a saúde e humor da filha era imprevisível e ditava boa parte do dia: 
É meio, assim... Não tem muito uma rotina. Eu até tentei fazer. Tenho um papelzinho lá na minha parede, né... Da rotina que a gente deveria seguir. Mas não tem muito uma rotina. Depende muito de como ela tá no dia. Tem dias que ela tá muito boazinha, tem dias que ela tá “da pá virada”. (Beatriz).

Carlos, por sua vez, ao ser perguntado sobre sua rotina, falou predominantemente de suas aulas e seu tempo livre com a filha, o qual ele diz ser muito prazeroso:

Então desde dar papá, de dar banho, de brincar com ela, de assistir alguma coisa, de passear, é sempre pensando no conforto dela. A gente sempre pensa no melhor pra ela. Não só porque ela é uma bebê, mas porque ela é minha filha. Então tudo o que eu faço por ela não ter qualquer peso, assim. É, tipo... Não tem um peso físico, nesse sentido. Não me sinto desgastado, não me sinto cansado. Então essa imagem mostra o meu carinho por ela, né? (...)E eu tento ao máximo levar ela pra passear de bicicleta quando o dia tá bom, levar ela pra brincar com outras pessoas (...). Aí no tempo que a gente passa junto a gente ouve música, (...) assiste os desenhinhos que ela gosta de assistir. Esses são os momentos que mais assim, eu não penso em nada da universidade. não respondo no WhatsApp, nem nada da universidade. não abro e-mail, fico só com ela mesmo (...) e quando eu preciso fazer alguma coisa, e ela quer ficar grudada em mim - sei lá, preciso lavar louça ou fazer comida -, eu coloco ela na cadeira e boto pra ela assistir uns desenhos. (Carlos).

Assim como os demais, a grande parcela de tempo livre de Ana era dedicado ao lazer com/da filha, especialmente nos fins de semana, juntamente com a realização de tarefas domésticas:

Quando a gente chegou na cidade a gente não conhecia nada, aí todo dia a gente ia pro shopping (...) aí agora eu procuro pesquisar (coisas novas) (...) teve o trem, que a gente adora, e procura levar no final de semana. Aí final de semana procuro fazer algo diferente aqui na cidade mesmo. Esse final de semana que tava calor ela brincou bastante com água. Cozinhar, todo final de semana a gente faz bolo, aí também pega pra lavar roupa, limpar a casa. Ajuda um pouco, atrapalha um pouco, mas a gente deixa pra ela já ir aprendendo, pra pegar um pouco de vivência, e ir..."; "Até final de semana passado, eu precisei ficar estudando pra uma prova de cálculo e aí meu marido foi com ela para um parque da cidade. (Ana).

Mateus, seguindo o mesmo padrão de estudos durante o dia e demais atividades a noite ou durante os fins de semana, descreveu sua rotina da seguinte forma:

A noite a rotina deles e isso, é dar banho e preparar pra dormir, brincar um pouco - mas não brincadeira muito agitada, mais assim pra eles relaxarem , conversar de algo da escola, fazer alguma atividade que tem da escola. É 
mais essa rotina. Final de semana, a gente tenta marcar de ir no parque, Sesc - estamos indo bastante no Sesc, uma das principais opções de lazer aqui, acho que é o único lugar garantido que tem opção de lazer. Aí ver algo que tem na cidade, ou algum parque que tem na cidade(...). Mas desde que eu comecei a fazer as corridas pelo aplicativo eu tenho ficado menos de final de semana com eles, tenho ficado mais trabalhando ou descansando. Isso aí faz uns 4 meses. Antes a gente tava todos os finais de semana fazendo algo juntos, mas agora que eu tô trabalhando mais dificilmente eu tô com eles no final de semana. (Mateus).

Dessa forma, fica visível a dificuldade em conciliar tantas tarefas, uma vez que tanto universidade quanto maternidade/paternidade são tarefas dispendiosas e, muitas vezes, cansativas. Assim, marcadas por um grande contingente de tarefas domésticas, parentais e universitárias, a rotina dos participantes se adequa à realidade de cada um, seja mais dificultosa e limitada à lógica universidade vs. filho, seja mais livre e aberta para atividades de outras naturezas.

\section{Vida social}

Devido às dificuldades de conciliar a rotina, a vida social dos participantes foi outro aspecto que sofreu modificações após o nascimento dos filhos. Ana, ao ser perguntada sobre o assunto, disse: "Essa foto foi de um dia que a gente foi comer cachorro quente, aí o Vinícius ficou com a Maria. Esse ano foi a primeira vez que eu saí sem (a filha), mas acho importante isso também”.

Os homens, por outro lado, demonstraram manter maior atividade social, saindo com amigos e sem o filho com maior frequência que as mulheres. Carlos, por exemplo, relatou:

Porém de quarta a noite eu não tenho aula, aí geralmente eu vou ver meus amigos (...). A gente sai pra tomar um sorvete ou pra tomar uma cerveja, ou comer um lanche, enfim só ficar conversando ali no período da noite, porque a gente se vê sempre no período de aula. Aí nesse período a gente aproveita pra bater um papo sobre a vida. (Carlos).

Mateus, além de manter contato com grupos formados por outros pais e fazer parte e uma comunidade de economia solidária, também sai com seus amigos esporadicamente: "A gente tem um grupo de estudantes com filhos, temos os amigos que tão na pós pra poder jogar bola".

Dessa forma, nota-se que ainda que exista diferenças para cada um dos gêneros - mais responsabilizadas pelo cuidado com as crianças (Walsh, 2016) e julgadas ao saírem, as mulheres demonstraram sair com menos frequência do que os 
homens, e em geral, tem seus momentos de lazer no ambiente familiar (Gonçalves \& Ternovoe, 2017). Contudo, cumpre destacar que a vida social de todos os participantes sofreu mudanças. Além do sentimento de distanciamento dos colegas de sala, como já discutido anteriormente, também pode-se notar que sair com os amigos se tornou mais difícil para os participantes, uma vez que o tempo disponível para isso diminuiu, como observado em outros estudos (Behar, 2018; Cardoso, 2017) frente a tantas obrigações com a universidade e com os filhos.

\section{Motivação}

A motivação, sobretudo no que diz respeito a permanecer estudando, foi um ponto que apareceu de forma muito similar no discurso de todos os participantes, relacionadas com os filhos e com o futuro.

Sobre os filhos, foi relatado o quanto o que esses jovens têm seu foco em realizar quase todas as atividades por eles, de formas menores ou maiores. Como foi descrito anteriormente, a renda tem a função de dar uma melhor condição de vida e conforto para os filhos e a família (Gonçalves \& Ternovoe, 2017), o desempenho acadêmico melhorado também é em função dos mesmos. Além disso, como relatado por Beatriz, ter tido o filho houve uma mudança na percepção sobre ela própria, e isso a motiva: "Eu me sinto forte! É uma força que eu achei que eu não ia ter".

A visão de futuro ainda é relacionada aos filhos, desta vez sendo pensada de que as dificuldades que estão ocorrendo agora são para dar um futuro melhor para as crianças, como exemplificado no relato de Ana:

E é um esforço que a gente faz agora pro futuro sabe, tô estudando agora pra mais pra frente ter uma condição melhor, de dar uma vida melhor pra ela $(f i l h a)$, porque hoje em dia com graduação tá difícil arranjar emprego, sem graduação tá impossível, realmente tudo que eu faço acho que gira um pouco em torno dela. (Ana).

Além disso, existe o foco de que essa fase difícil vai passar, e as situações ficarão melhores, como dito por Ana, mas relatado de maneira ainda mais clara por Beatriz:

Penso assim: tá difícil, tá puxado, mas vai melhorar. Vai ficar tranquilo. "Tranquilo" eu não sei, que toda a fase da vida alguma coisa... aparece um obstáculo. Mas estou tentando. E minha motivação é que passe o quanto antes e que eu consiga respirar tranquila. (Beatriz). 


\section{Sugestões}

De acordo com a literatura, e com os relatos dos entrevistados, existem diversas dificuldades apresentadas pela população de jovens universitários que não são apresentadas por outros estudantes da universidade. Por este motivo, foi perguntado para os participantes se os mesmos tinham alguma sugestão de ações por parte da universidade para que houvesse uma melhora para pessoas na mesma situação que eles se encontram.

O primeiro ponto citado foi quanto às vagas da creche ligada à universidade, que como dito anteriormente são previstas como direito de alunos com auxílio financeiro da universidade, no entanto os outros estudantes participam de um sorteio das vagas juntamente com a população geral da cidade. Assim, a sugestão dada pelos participantes foi da disponibilidade de vagas na creche ligada à universidade para os filhos de todos os estudantes da dada universidade. Desta forma, eles seriam auxiliados de diversas formas, como na financeira, por não ser necessário que se pague uma creche para a permanência dos filhos, e na acadêmica, por não ser necessário a presença em aulas juntamente com o filho.

Além da importância da creche, foi citada a importância de um espaço para as crianças e seus pais, para que mesmo quando a creche estiver fechada os mesmos tenham um espaço adequado para permanecerem, sendo também um local de convivência e lazer adequados para as necessidades das crianças e de seus pais, como relatado por Mateus: "seria um espaço para crianças dentro da universidade além da creche, pra quando tivesse fechada, ou se o estudante não tem vaga na creche, que seria um espaço de convivência focado nas crianças mesmo". Assim, esse local ajudaria os estudantes com filhos a terem mais espaços de pertencimento dentro da universidade, e podendo auxiliar a tornar menos difícil o seu cotidiano com a rotina de estudante e de pai. Essa ideia já foi proposta pelo grupo de pais estudantes, o GMPU, para a gestão da universidade, no entanto em mais de dois anos não saiu dos planos para a realidade.

Outra ideia dada pelos participantes também foi de conversas, no estilo roda de conversa, sobre o assunto da parentalidade na universidade, para que esses estudantes tenham um espaço de fala e até mesmo de troca de experiências, com a possibilidade de alunos que não tem filhos também participem e consigam entender 
melhor a situação de seus colegas, o que poderia possibilitar uma maior organização dos alunos para cobrar da universidade as suas reivindicações.

As sugestões apresentadas pelos entrevistados se mostraram extremamente pertinentes para a experiência que os mesmos têm na universidade e as dificuldades apresentadas por eles em lidar com as questões universitárias e parentais. Notou-se também que parte dessas sugestões já foram levadas para a gestão da universidade, por meio dos representantes do grupo de pais estudantes, o GMPU, e infelizmente a demanda apresentada ainda não foi suprida.

\section{Gênero}

Apesar da pesquisa não se propor a analisar de forma aprofundada questões de gênero, a escolha de participantes homens e mulheres foi pensando em não ser um fator limitante para as análises.

Durante a fase de recrutamento de participantes, as pesquisadoras notaram a dificuldade em se localizar homens com filhos que se encaixavam nos critérios da pesquisa. Notou-se também que os parceiros das mulheres que se encaixavam no critério de idade inicial (de 18 a 25 anos), e que entraram em contato para a participação na pesquisa, tinham idades mais avançadas, em geral a partir de 30 anos. Por esse motivo foi necessária a mudança nos critérios de idade dos participantes.

Além disso, nos relatos dos participantes, foi possível notar que mesmo nos casos em que há grande divisão de tarefas do cuidado dos filhos, era relatado pelos homens mais experiências de lazer, como sair com os amigos, esportes e eventos, do que nas mulheres, que diziam ter a maior das suas atividades, mesmo de lazer, ainda junto com os filhos. Esse fator se apresentou independentemente da idade dos filhos.

Já nos casos de falta da divisão de tarefas, uma jornada tripla das participantes era notada, como estudantes, mães e donas de casa, o que levava a uma sobrecarga física e emocional, o que afeta de forma preocupante a qualidade de vida dessas mulheres (Gonçalves \& Ternovoe, 2017; Salgado, 2019).

A literatura demonstra que a diferença de gênero se apresenta desde a gravidez, com as mulheres sendo descritas como promíscuas ou então vítimas de homens mais velhos (Smithbattle, 2007), além da visão que os pais também sofrem de que seriam mães e pais ruins, por serem jovens, e que arruinaram suas chances na vida (Conn et al, 2018). Além disso, em questões de estudo e mercado de trabalho, 
a diferença de gênero também é grande, sendo que quando mulheres têm filhos mais cedo em sua formação (cedo, neste dado, sendo considerado até cinco anos após ser pós graduada), as mesmas têm menos chance de ser bem sucedida e de terem suas especificidades compreendidas do que os homens na mesma situação.

Esses dados da pesquisa em união com a literatura só deixam mais claro que a diferença entre os gêneros na sociedade ainda é grande, e que o impacto de ter filhos e ser universitário também é diferente para homens e mulheres.

\section{Considerações finais}

Considerando, portanto, os resultados obtidos na presente pesquisa, tanto por meio do relato dos participantes quanto por meio da revisão de literatura sobre a dificuldade dos universitários com filhos conciliarem a demanda da parentagem com os estudos, pode-se afirmar que é de extrema importância explorar e compreender cada vez mais as vivências de dessa população, uma vez que estes são um grupo repleto de singularidades a serem estudadas, com demandas a serem ouvidas. Estudos como este ainda são escassos no Brasil e no mundo (Vieira et al, 2019), e são essenciais para trazer visibilidade para estes indivíduos, com suas experiências particulares, fatores que trazer apoio ou que dificultam suas vidas ao conciliar dois papéis tão importantes e complexos.

Assim, o presente estudo auxilia não só neste aspecto, como também aponta a necessidade da inclusão de pontos específicos a essa população no PNAES (Plano Nacional de Assistência Estudantil), ou criação de outras políticas públicas, que possam levar a modificações estruturais, culturais ou de gestão nas universidades.

Analisando todos os dados, pode-se afirmar que grande parte dos relatos obtidos vão de encontro com a literatura já produzida sobre o assunto: uma vivência marcada por dificuldades de conciliação entre a maternidade/paternidade e os estudos é realidade, onde assistir aula, cumprir prazos e lidar com as demais demandas da universidade são dificultados pela necessidade de cuidar do filho. Entretanto, tal realidade não quer dizer que conduzir ambas tarefas simultaneamente seja impossível.

$\mathrm{Na}$ verdade, a pesquisa demonstra que, quando oferecido o devido suporte, é possível lidar com grande parte das dificuldades. Dentre tais suportes, ressalta-se o apoio de indivíduos de confiança e o apoio institucional da universidade, que deve fornecer alternativas à estudantes que possuem filhos, tal como flexibilidade para prazos e 
presença em aula, e, principalmente, com vaga em creches de universidades, para os filhos de todos os alunos.

Ademais, ao contrário do que a indicam os estudos existentes, que apontam para a diminuição do rendimento acadêmico de mulheres ao terem filhos, devido à colisão pouco conciliável de tarefas acadêmicas e maternais (Manalang, Liongson \& Bayubay, 2015), os dados demonstraram, de forma consistente, que o desempenho acadêmico de jovens universitários pode sofrer melhoria após o nascimento de filhos, uma vez que estes entendem a universidade como um ambiente que oferece inúmeras possibilidades de alcançar estabilidade e prover boas condições para os filhos no futuro.

Ainda que tragam muitos dados relevantes e atuais, é preciso ressaltar que a pesquisa aqui relatada apresenta limitações devido ao número de participantes (dois homens e duas mulheres), e à ausência de análise de dados socioeconômicos. Ademais, todos os indivíduos fazem parte de uma mesma universidade localizada no interior do estado de São Paulo, não sendo, portanto, possível estabelecer generalizações para além deste contexto.

Outrossim, mesmo que muitos pontos dos relatos dos participantes sejam similares aos de outros estudos, ainda são encontradas especificidades interessantes, que devem ser estudadas mais a fundo, de forma a compreender melhor tais diferenças e suas causas. Além disso, o presente estudo se coloca como relevante na sociedade atual ao dar voz à uma população usualmente invisibilizada, apontando para a criação de políticas públicas que mudem essa realidade, juntamente com alterações no PNAES, e também mudanças estruturais e administrativas no que diz respeito às universidades públicas brasileiras.

\section{Referências}

Bardin, L. (2009) Análise de Conteúdo. Lisboa: Edições 70.

Behar, R.C.R. (2018) A maternidade e seus impactos nos papéis educacionais de primíparas. Monografia (Graduação). Universidade Federal da Paraíba.

Brito, R. C.\& Koller, S. H. (1999) Desenvolvimento humano e redes de apoio social e afetivo. In: Carvalho, Alysson Massote (org.). O mundo social da criança: natureza e cultura em ação. São Paulo: Casa do Psicólogo. 
Bronfenbrenner, U. (1996). A ecologia do desenvolvimento humano: Experimentos naturais e planejados (M. A. V. Veronese, Trad.). Porto Alegre: Artes Médicas. (Original publicado em 1979)

Cardoso, C.P. (2017) Experiência da Maternidade em Mães Adolescentes. Dissertação de mestrado. ISPA - Instituto Universitário das Ciências Psicológicas, Sociais e da Vida

Conn, B. M., de Figueiredo, S., Sherer, S., Mankerian, M., \& Iverson, E. (2018). "Our lives aren't over": A strengths-based perspective on stigma, discrimination, and coping among young parents. Journal of Adolescence, 66, 91-100. https://doi.org/10.1016/j.adolescence.2018.05.005

Dell'aglio, D.D. \& Siqueira, A. C. (2012). Avaliação da rede de apoio familiar: A utilização do Mapa dos Cinco Campos. In: Makilim Nunes Baptista; Maycoln L. M. Teodoro. (Org.). Psicologia de família: Teoria, avaliação e intervenção. 1ed.Porto Alegre: Artmed, 225-239.

Flick, U. \& Von Kardorff, E. \& Steinke, I. (2000) O que é pesquisa qualitativa? Uma introdução. Porto Alegre: Artmed.

Fonaprace, Andifes (2016). IV Pesquisa do Perfil Socioeconômico e Cultural dos Estudantes de Graduação das Instituições Federais de Ensino Superior Brasileiras 2014 - Uberlândia, Brasil.

Gabardo-Martins, L. M. D. \& Ferreira, M. C. \& Valentini, F. (2017). Propriedades psicométricas da escala multidimensional de suporte social percebido. Temas em Psicologia, 25(4), 1873-1883. https://dx.doi.org/10.9788/TP2017.4-18Pt

Gonçalves, J. P., \& Ternovoe, J. dos S. (2017). Desafios Vivenciados por Mulheres Universitárias de Mato Grosso do Sul, que são Mães, Profissionais e Donas de Casa. Revista Latino-Americana de Geografia e Gênero, 8(2), 116-142. https://doi.org/10.5212/Rlagg.v.8.i2.0006

Harper, D. (2002). Talking about pictures: A case for photo elicitation. Visual Studies, 17(1), 13-26. https://doi.org/10.1080/14725860220137345

Hirst, J., Formby, E., \& Owen, J. (2006). Pathways into Parenthood: Reflections from Three Generations of Teenage Mothers and Fathers. Sheffield: Sheffield Hallam University. 
Juliano, M. C. C., \& Yunes, M. A. M. (2014). Reflexões sobre rede de apoio social como mecanismo de proteção e promoção de resiliência. Ambiente \& amp; Sociedade, 17(3), 135-154. https://doi.org/10.1590/S1414-753X2014000300009

Kershaw, T., Murphy, A., Lewis, J., Divney, A., Albritton, T., Magriples, U., \& Gordon, D. (2014). Family and relationship influences on parenting behaviors of young parents. The Journal of Adolescent Health: Official Publication of the Society for Adolescent Medicine, 54(2), 197-203. https://doi.org/10.1016/j.jadohealth.2013.08.012

Liebenberg, L. (2009). The visual image as discussion point: Increasing validity in boundary crossing research: Qualitative Research. https://doi.org/10.1177/1468794109337877

Maidel, S, \& Vieira, M. L. (2015). Mediação parental do uso da internet pelas crianças. Psicologia em Revista, 21(2), 293-313. doi: 10.5752/P.16789523.2015V21N2P292

Manalang, D. C., Liongson, P. A., \& Bayubay, E. N. T. (2015). The Lived Experiences of College Student Mothers in Managing their Dual Roles: An Exploratory Study. Tese de doutorado do departamento de psicologia, college of Art and Science, Angeles City: Angeles University foundation.

Melo, F. M. de S., Santos, M. P., Sousa, L. B. de, Holanda, V. M. de S., Araújo, M. F. M. de, \& Joventino, E. S. (2018). Experiências de estudantes internacionais ao gestar longe do seu país de origem. Avances en Enfermería, 36(3), 355-364.

Mesquita, A. P. de, Silva, G. F. da, Santos, C. A. N. dos, Pereira, L. A. da S., Dias, F. M. R., Vasconcelos, M. H. dos S., Leite, E. P. C. C., Teixeira, J. K. S., Leoncio, A. K. S., \& Rodrigues, E. B. (2019). "Quem pariu Mateus que balance": A reprodução do patriarcado e a solidão das mulheres/mães universitárias no cuidado com os/as filhos/as. Congresso Brasileiro de Assistentes Sociais 2019, 16(1), Article 1. http://broseguini.bonino.com.br/ojs/index.php/CBAS/article/view/722

Nikolaeva, S. (2018). A normal student parent. Science, 362(6411), 258-258. https://doi.org/10.1126/science.362.6411.258

Nikolaeva, S. A (2018). Making Myself Visible as a Grad Studant Parent. Science, 362, 6411, 258-258, New York. doi: 10.1126/science.caredit.aav6930 
Peres, S. O., \& Heilborn, M. L. (2006). Cogitação e prática do aborto entre jovens em contexto de interdição legal: O avesso da gravidez na adolescência. Cadernos de Saúde Pública, 22(7), 1411-1420. https://doi.org/10.1590/S0102-311X2006000700006

Rapoport, A., \& Piccinini, C. A. (2006). Apoio social e experiência da maternidade. Journal of Human Growth and Development, 16(1), 85-96.

Salgado, D. G. (2019). Qualidade de vida de mulheres com tripla jornada: mães, estudantes e profissionais. Pretextos - Revista da Graduação em Psicologia da PUC Minas, 4(8), 308-320.

Smithbattle, L. (2007). Legacies of advantage and disadvantage: The case of teen mothers. Public Health Nursing (Boston, Mass.), 24(5), 409-420. https://doi.org/10.1111/j.1525-1446.2007.00651.x

Terra, A. P. R. (2019) Dificuldade de Integração das Estudantes Grávidas e Jovens Mães na Universidade e no Estágio: existe um perfil de mulher acadêmica? Trabalho de Conclusão de Curso (Graduação em Direito) - Universidade Presbiteriana Mackenzie, São Paulo, Brasil.

Tomazi, A.; Sebastiany, M.M.; Escobar, A.V.; Lerner, F.C.; Duarte, L.R.; Da Fonseca, L.R.S.C.M. \& Pletiskaitz K. (2016) Educação Superior e Gênero: A Assistência Estudantil às Mães Estudantes nas IFes do RS. (2016) Anais do Salão Internacional de Ensino, Pesquisa e Extensão, 8 (2), Bagé, Rio Grande do Sul.

Urpia, A. \& Sampaio, S. M. R. (2011) Mães e universitárias: transitando para a vida adulta. Observatório da vida estudantil: primeiros estudos [online]. EDUFBA, 145-168.Salvador. doi: 10.7476/9788523212117

Vieira, A. C., Souza, P. B. M. de, \& Rocha, D. S. da P. (2019). Vivências da maternidade durante a graduação: Uma revisão sistemática. Revista Cocar, 13(25), 532-552.

Walsh, F. (2016). Diversidade e complexidade nas famílias do século XXI. In: Walsh, F. (Org.), Processos normativos da familia: diversidade e complexidade (pp. 3-27). Porto Alegre: Artmed.

Submetido em: 27/03/2020

Aprovado em: 03/06/2020 
